\title{
MILLENNIALS AND TRAVELING TO DOMESTIC DESTINATION
}

\author{
Ramadania RAMADANIA* \\ Universitas Tanjungpura, Faculty of Economics and Business, Indonesia, e-mail: ramadhania@ekonomi.untan.ac.id \\ Yahya Al FATIH \\ Universitas Tanjungpura, Faculty of Economics and Business, Indonesia, e-mail: yahyaelfath96@student.untan.ac.id \\ Dio Caisar DARMA \\ Samarinda High College of Economics, Department of Management, Indonesia, e-mail: diocaisar@ stiesam.ac.id
}

Fenty FAUZIAH

University of Muhammadiyah Kalimantan Timur, Faculty of Economics Business and Political, Indonesia, e-mail: ff230@umkt.ac.id

Citation: Ramadania, R., Fatih, Y.A., Darma D.C., \& Fauziah, F. (2021). MILLENNIALS AND TRAVELING TO DOMESTIC DESTINATION. GeoJournal of Tourism and Geosites, 35(2), 398-405. https://doi.org/10.30892/gtg.35218-664

\begin{abstract}
In this period, traveling has become one of the activities most in demand by the community, many people try to get rid of boredom by switching to traveling. The purpose of this research is to investigate the impact of lifestyle among millennials on their attitude toward traveling activities. We use survey research that is conducted to understand the causal relationships between variables with the use of a questionnaire as the instrument to obtain data. The questionnaire is distributed to 100 samples who fulfill the requirements. The sample is millennials in Pontianak City who are between 20 - 39 years old. The data analysis method used is Structural Equation Model Partial Least Square (SEM-PLS) method using SmartPLS 3.0 software. The hypothesis is the lifestyle and travel motivation have an effect to tour preferences. Furthermore, lifestyle, travel motivation, and tour preferences have an effect on consumer intention to travel. The result of this research shows that all the hypotheses are accepted. Not a few people think traveling has become a hobby and lifestyle because traveling itself has become a trending topic in the community.
\end{abstract}

Key words: lifestyle, travel motivation, tour preferences, traveling, millennials

$* * * * * *$

\section{INTRODUCTION}

With the rapid advances in technology and the increasing global availability and accessibility of digital channels for information/media distribution, sharing the daily activities in social media has become a habit for people around the world, things that are normally shared on their social media are usually in the form of a photo of activities or writing scribbles about their feelings or opinions that are related to the environment around them (Darma et al., 2020). With new habits arising in the community some activities become so popular, like traveling, martial arts (karate and muay Thai), and hang out at Cinema. In this period, traveling has become one of the activities most in demand by the community, many people try to get rid of boredom by switching to traveling, and not a few people think traveling has become a hobby and lifestyle because traveling itself has become a trending topic in the community. Generally, traveling activities will be made a topic on their social media accounts to show what they have done (Ratnasari et al., 2020; Suharto et al., 2019).

Travel motivation is the one that drives people to do travel activities, people tend to travel when they need to get out of their daily activities, they need some refreshment of their mind and body, so they choose traveling as their reflexing moment or as a new exploration to the new place they haven't seen before. So it can be concluded that travel motivation can influence the tour preferences, we can see from their motivations when people want to have a relaxing moment, tour preferences also have escape activities, and when they want to explore a new place, tour preferences also have adventure activities, these two variables have a positive correlation. Research conducted by Prebensen (2016), these studies revealed Norway people tend to choose to explore the new place. She stated that motivation is the most influencing factor and improvement in the service attributes of the journey would contribute to increased overall satisfaction with the journey. Individuals with active, energetic, and adventurous extraversion tendencies will love outdoor activities (Tran et al., 2015). Vuurent and Slabbert (2012) revealed that the tour preferences can drive people to travel, and most of the travelers motives were to rest and relax, to participate in exciting activities, to partake in enriching and learning experiences, social interaction, and certain personal values. Market tastes can be known by studying the needs and desires of consumers through psychographic segmentation by classifying the lifestyle or personality of the traveler (Jannah et al., 2018), these research results indicated that it is clear that tourism marketers are required to do research on a continuous basis in order to determine tourists' travel behavior.

With the development of technology and the many lifestyles of this era, many millennials have various activities influenced by their lifestyles. Sometimes what they often do will become the benchmark of society in assessing the young

\footnotetext{
* Corresponding author
} 
generation (Chivandi et al., 2020). So it can be concluded, that lifestyle is a pattern of life where there is a meeting point between the needs of self-expression with the hope of a particular group is expressed in activities, int sts, and opinions. No doubt lifestyle is often used as group identity. The lifestyle of each group will have its own characteristics. Thus, the lifestyle of society is different from other societies. Lifestyle also can bring us the insight of the people's want in their traveling, and lifestyle is often used as group identity therefore people that care much for their self-images and prestigious things, could be using their money for the expensive tour packages that were provided by the travel agents, they don't care about spending a lot of money to get the luxury one, because what they really want are being recognized by people around them. They will feel shame when they can't get the best services during their travel activities. The examples above indicated that lifestyle patterns could be used to identify the consumer market segments, and that lifestyle dimensions influence consumer behaviors. Previous research indicated that lifestyle variables can provide more effective and efficient marketing information about a tourist as a customer than demographic or socio-economic variables (Plummer, 1979; Zins, 1998). We can see from the examples above, that lifestyle could be the important variable to get the pattern of tourist's behavior because lifestyle directly bring us to their personal life, and this is a big chance for tourism industries to expand their businesses to fulfill the demand of people.

Millennials are known as the icon of the youth generation, and they have their lifestyle and communities that special just for them, they have a great posture of the body, good thinking, and high curiosity. Most of their life is a challenge for them to show their abilities and their presence. Traveling has become one of the ways to show others about themselves, some of them travel by their own, and others using the travel agencies, both of them become their way to show people that they can do it, those who do it by themselves try to show that they are independent and capable doing anything by their own, and the one who uses the travel agencies they try to show others that they can trip with luxury services and indirectly affect other millennial about the image of traveling (Kamri et al., 2020). Considering generating opportunities for the resource potential of regions and public relations of individual enterprises in the production, distribution, exchange, and consumption of tourism products (services) that arise in the implementation of tourism and a number of related types of activity (Kala et al., 2017). Destination of traveling can be anywhere, it can be the view of the modern city, it can be a beautiful landscape of mountain, beach or sea, and even just a small village in the remote parts of the country (Ushakov et al., 2020). Indonesia provides all of the destinations that travelers want to visit. There are Jakarta, Surabaya, and Bandung that provide the modern city and a modern culture rather than other regions. Bali, Lombok, Raja Ampat provide a beautiful landscape of mountains, beach, and seas. Banten provides Baduy village for the one who wants to know about local Sundanese, Papua provides Tablanusu village for the one who wants to know more about local Papuans, and the other places.

\section{LITERATURE REVIEW}

\section{Theoretical Approaches}

According to Prasetijo and Lhalauw (2015) lifestyle is born from a mindset that becomes, this mindset that forms a person's perspective to do various activities becomes a habit. Meanwhile, Parubak (2010) explains that lifestyle will give a picture where lifestyle will determine someone in choosing what they want, where the phenomenon will shape one's mindset. Hsu and Chang (2008) explained that lifestyle can have an impact on purchasing behavior that has a relatively large influence, while lifestyle is an outside characteristic that can be observed and can be used in strategic marketing (Gonzáles and Bello, 2002). It has been stated that lifestyle variables are built based on the activities, interests, and opinions that exist in the overall consumer behavior model. Gerrig and Zimbardo (2002) define motivation as the general term for all the processes involved in starting, directing, and maintaining physical and psychological activities. Travel motivation is considered an important field in the tourism research literature, the prediction and knowledge of travel motivation plays an important role in tourism marketing, in order to create demand and assist tourists in decision-making (Decrop, 2006).

Thus by having adequate knowledge and understanding of travel motivation, strategies, and policies can be developed and implemented to increase the demand for tourism (March and Woodside, 2005). Travel preference is a selection of travel types, there are a lot of types that can be chosen for the traveler to do travel (Ashworth and Goodall, 1990). Travel types are one of the options that can give an insight of the traveler to do travel with the kind of model traveling they want, and this is the chance for the travel agency to give support to the traveler with providing the tour packages, and there are four effective characteristics of a tours preferences-adventurous, cultural, business-related, and escaping (Abbey, 2004). Consumer intention to traveling refers to the degree in people's minds to do travel posits that behavioral intentions, rather than attitudes, are the main predictors of actual behavior (Fishbein and Ajzen, 1975). There are effective characteristics of behavior when people or consumers have the intention to do something, in this case, is traveling-willingness, financial support, and positive attitudes (Ajzen, 2020).

\section{Hypothesis Development}

The application of lifestyle segmentation could provide a unique and important view of the tourism market. The concept of lifestyle is defined as patterns in which people live and spend their time and money reflecting on people's activities, interests, and opinions. Calantone and Johar (1984) stated that lifestyle also could be a useful variable for tourism marketers, not only to classify customers and examine the differences of travelers, but also to predict tourist consumption behavior by looking at their activities, interests, and opinions which are based on their ways of living. So the variable of lifestyle will become the new study for this research. Previous research explained that most travelers are affected by their own motivation, Kozak (2002) tested the factor structure of this measure and found that it comprised four dimensions of motives: cultural motives, pleasure-seeking/fantasy-based motives, relaxation-based motives, and physical motives. Cultural motives (3 items) involve cultural reasons for visiting the destination (e.g., "I visit Barbados to meet the local people"). Pleasure-seeking motives (4 items) involve reasons based on the need to find pleasurable and enjoyable experiences in the destination (e.g., I came to 
Barbados to seek adventure"). Relaxation-based motives (4 items) are based on the need to find peace, tranquility, and relaxation in the destination (e.g., "I came to Barbados to be emotionally and physically refreshed"). Physical motives (3 items) are based on the need to find opportunities to be physically active during one's stay in the destination (e.g., "I came to Barbados to engage in sports"). These are the motives that usually people have when they decided to travel.

Travel preference is a selection of travel types, there are a lot of types that can be chosen for the traveler to do travel (Ashworth and Goodall, 1990). As Abbey (2004) stated there are four affective characteristics of a tour's preferences adventurous, cultural, business-related, and escaping. The type of tour preferences from this research can be assumed to have a relationship with the travel motivation itself, so both variables can affect one another.

Cizmar and Weber (2000) pointed out, destination choice remains one of the first and most important decisions made by tourists; and this decision, in turn, is, to a large extent, subject to a number of external factors, such as country image, accessibility, attractiveness, safety, etc. Destination choice, on the other hand, also determines inter-enterprise competition between airlines, tour operators, hotels, and other tourism services (Ritchie and Crouch, 2000). Consumer intention to traveling refers to the degree in people's minds to do travel posits that behavioral intentions, rather than attitudes, are the main predictors of actual behavior (Fishbein and Ajzen, 1975). After they all know what they are searching for this journey or travel activities.

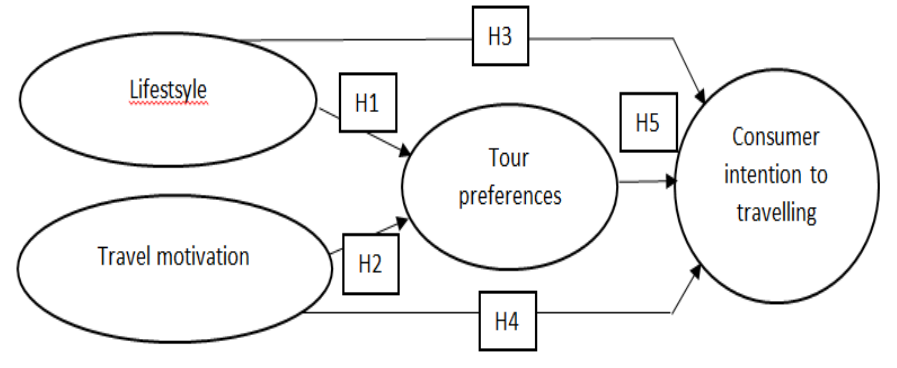

Figure 1. Conceptual framework
From Figure 1, the formulated hypotheses are depicted beside the arrows on the conceptual framework. Scholars believed that lifestyle is one of the consideration factors affecting tour preferences (Chen et al., 2009). Backman et al. (1999) used 46 AIO measurements to categorize senior nature-based travelers and to determine whether differences and similarities between the groups exist. The result of the study stated that senior nature-based travelers are looking for different packages of benefit; in sum, lifestyles are very useful to marketers of nature-based travel products. Therefore, the first hypothesis is formulated, as follows:

\section{H1-The lifestyle has an effect to tour preferences.}

Research conducted by Vuurent and Slabbert (2012) condungting results revealed that the tours preferences can drive people to travel, to participate in exciting activities, to partake in enriching and learning experiences, and social interaction and certain personal values. Mohamad and Jamil (2012) stated that most of the motives can be aligned by the tour preferences, and it really helps the traveler and the business sector to collaborate. Based on theoretical support, the second hypothesis is formulated:

\section{H2-The travel motivation has an effect to tour preferences.}

Calantone and Johar (1984) stated that lifestyle also could be a useful variable for tourism marketers, not only to classify customers and examine the differences of travelers, but also to predict tourist consumption behavior by looking at their activities, interests, and opinions which are based on their ways of living. Chen et al. (2009) said that lifestyle can be a booster for the people to choose traveling as their activities to spend their time. It does not rule out the possibility that people can be driven by their lifestyle to choose traveling as their activities. Hence, it is concluded that:

\section{H3-The lifestyle has an effect on consumer intention to travel.}

Thus by having adequate knowledge and understanding of travel motivation, strategies and policies can be developed and implemented to increase the demand for tourism (March and Woodside, 2005), travel motivation can drive people from the inside, it's what a person wants. People tend to move because of what they want, and that is how the travel motivation works when they know exactly what they want it makes them easy to do traveling. Tourists expect and believe that going on a vacation can partly or fully different needs and wants (Mill and Morrison, 1985) intrinsic and extrinsic motivation can figure tourist motives out, intrinsic motivation is about individual needs to encourage themselves going travel. For example, tourists travel for self-improvement or self-realization. It can make them have happiness, fulfillment, and ego-enhancement. So the fourth hypothesis is formulated:

\section{H4-The travel motivation has an effect on consumer intention of traveling.}

Travel types are one of the options that can give an insight of the traveler to do travel with the kind of model traveling they want, and this is the chance for the travel agency to give support to the traveler by providing the tour packages (Oppermann, 1999). Tour preferences move as a guidebook which by using it we can find out and get what we want and it can be driven for people to do traveling as well (Abbey, 2004). It can be concluded that tour preferences are making easier for the traveler to choose the types of traveling they want. The last hypothesis is:

\section{H5-The tour preferences have an effect on consumer intention to traveling.}

\section{MATERIALS AND METHODS}

This study used a survey method. This research is explanatory and analyzed quantitatively, the primary data in this study were obtained from online and printed questionnaires. The raw data were subsequently proceeded using SmartPLS 3.2.7 for Windows to determine the frequency of responses from the respondents. Likert scale was employed to measure research variables in which the respondents were asked to indicate a degree of agreement and disagreement about the variables and ranged between 1-5, from very low to very high (Heffner, 2016). The research population was classified as infinite; hence, as the sample, this research used purposive sampling which was determined after the samples fulfilled certain criteria. The minimum 
sample size shall be 100-150 to ensure stable Maximum Likelihood Estimation (MLE). The total sample in this research was 100 respondents who were identified as a potential traveler (Hair et al., 2020). PLS began with testing the measurement model to test the validity of constructs and reliability of instruments. The validity test in PLS was implemented through convergent validity test, discriminant validity test, and Average Variance Extracted (AVE) test. Furthermore, the reliability test was used to measure the consistency of items in measuring the variables. It can also be used to measure respondents' consistency in answering instruments. Overall, the response rate for online surveys was higher than the paper surveys in this research.

Table 1. Measurement of constructs

\begin{tabular}{|c|c|c|}
\hline \begin{tabular}{c|c} 
Variable \\
\end{tabular} & Indicator & Item \\
\hline \multirow{3}{*}{$\begin{array}{l}\text { Lifestyle (X1) adapted } \\
\text { from González and } \\
\text { Bello (2002) }\end{array}$} & Interest & I have an interest in inviting my family and friends to go traveling \\
\hline & Opinion & My opinion and way of traveling make people around me want to go traveling \\
\hline & Activities & Going traveling to beautiful places is a positive thing. \\
\hline \multirow{4}{*}{$\begin{array}{l}\text { Travel motivation } \\
\text { (X2) adapted from } \\
\text { Kozak (2002) }\end{array}$} & Cultural motives & I have a motive for visiting cultural sites to go traveling \\
\hline & Pleasure-seeking motives & I have an adventurous motive and seek pleasure to travel \\
\hline & Relaxation-based motives & I have a motive to enjoy and relax to go traveling \\
\hline & Physical motives & I have a motive for using physical activities and plunging into nature to go traveling \\
\hline \multirow{4}{*}{$\begin{array}{l}\text { Tour preferences } \\
\text { (Y1) adapted from } \\
\text { Mohamad and Jamil } \\
\text { (2012) }\end{array}$} & Cultural activities & I want to travel because there is a collection of activity visits to cultural sites and cultural exchanges \\
\hline & Adventure activities & $\begin{array}{l}\text { I want to travel because there is a collection of visiting activities that challenge my } \\
\text { adrenaline in the wild. }\end{array}$ \\
\hline & Business activities & I want to travel because there is a collection of visiting activities that have business opportunities \\
\hline & Escape activities & $\begin{array}{l}\text { I want to travel because there is a collection of visiting activities to calm myself and my } \\
\text { mind in a quiet place. }\end{array}$ \\
\hline \multirow{3}{*}{$\begin{array}{l}\text { Consumer intention to } \\
\text { traveling (Y2) adapted } \\
\text { from Ajzen (1991) }\end{array}$} & Willingness & If I have free time I am willing to go traveling \\
\hline & Positive attitude & I look positively to visiting tourism destination \\
\hline & Financial support & If I have enough money I want to go traveling \\
\hline
\end{tabular}

\section{RESULTS AND DISCUSSION}

Millennials are people born between the early 1980s and the early 2000s which mean all the respondent should be over 20 years old until 39 years old. This research presents profiles of female and male respondents who were identified as eligible to fill the questionnaires which are required to be millennials. All respondents should be domiciled in Pontianak city, and they also should have been traveling or they have an intention to travel in the future (Dimock, 2015).

The total number of female respondents and a male respondent is almost balanced, the male is $51 \%$ and the female is $49 \%$. All respondents (100 informants) are interested in traveling activities, and most of them were undergraduate students 54\%. Those below 35 years old were estimated to be accounted for $92 \%$ of the total respondents. It was also observed that most respondents earned less than IDR 3 million for their monthly incomes (74\% of total respondents). The majority (48\%) of respondents were college students. Table 2 illustrates a summary of the characteristics of the respondents.

Table 2. Characteristics of respondents (Source: author's calculating)

\begin{tabular}{|l|l|c|c|}
\hline Category & \multicolumn{1}{|c|}{ Item } & Frequency & Percentage \\
\hline \multirow{4}{*}{ Gender } & Male & 51 & $51 \%$ \\
\cline { 2 - 4 } & Female & 49 & $49 \%$ \\
\hline \multirow{4}{*}{ Age } & $20-24$ & 64 & $64 \%$ \\
\cline { 2 - 4 } & $25-29$ & 26 & $26 \%$ \\
\cline { 2 - 4 } $\begin{array}{l}\text { Education } \\
\text { level }\end{array}$ & $30-34$ & 12 & $12 \%$ \\
\cline { 2 - 4 } & $35-39$ & 8 & $8 \%$ \\
\hline \multirow{5}{*}{$\begin{array}{l}\text { Income } \\
\text { level }\end{array}$} & Digh school & 52 & $52 \%$ \\
\cline { 2 - 4 } & Bachelor & 10 & $10 \%$ \\
\cline { 2 - 4 } & Master/Doctor & 12 & $26 \%$ \\
\cline { 2 - 4 } & $\begin{array}{l}\text { Rp.1.000.000 } \\
\text { Rp.3.000.000 }\end{array}$ & 43 & $43 \%$ \\
\cline { 2 - 4 } & $\begin{array}{l}\text { Rp.3.000.000 } \\
\text { Rp.5.000.000 }\end{array}$ & 16 & $31 \%$ \\
\cline { 2 - 4 } & $>$ Rp. 5.000.000 & 10 & $10 \%$ \\
\hline \multirow{5}{*}{ Occupation } & Student college & 48 & $48 \%$ \\
\cline { 2 - 4 } & Entrepreneur & 8 & $8 \%$ \\
\cline { 2 - 4 } & Private employee & 25 & $25 \%$ \\
\cline { 2 - 4 } & Civil servant & 10 & $10 \%$ \\
\cline { 2 - 4 } & Other profession & 9 & $9 \%$ \\
\hline
\end{tabular}

Table 3. Respondents by visited destination

\begin{tabular}{|c|c|c|}
\hline Destination that have been visited & Frequency & Percentage \\
\hline Jakarta & 72 & $72 \%$ \\
\hline Bandung & 65 & $65 \%$ \\
\hline Yogyakarta & 30 & $30 \%$ \\
\hline Bali & 22 & $22 \%$ \\
\hline Other destination & 100 & $100 \%$ \\
\hline
\end{tabular}

Table 4. Respondent by destination wants to visit

\begin{tabular}{|c|c|c|}
\hline Destination that will be visit & Frequency & Percentage \\
\hline Jakarta & 100 & $100 \%$ \\
\hline Bandung & 100 & $100 \%$ \\
\hline Yogyakarta & 56 & $56 \%$ \\
\hline Bali & 82 & $82 \%$ \\
\hline Lombok & 33 & $33 \%$ \\
\hline Raja Ampat & 40 & $40 \%$ \\
\hline Padang & 20 & $20 \%$ \\
\hline Surabaya & 15 & $15 \%$ \\
\hline Semarang & 7 & $7 \%$ \\
\hline Europe & 78 & $78 \%$ \\
\hline USA & 67 & $67 \%$ \\
\hline Asia & 85 & $85 \%$ \\
\hline Australia & 55 & $55 \%$ \\
\hline Other destination & 100 & $100 \%$ \\
\hline
\end{tabular}

Lifestyle does have a big influence on someone's traveling preferences, with different lifestyles making tour preferences indispensable to differentiate between travelers and this will greatly facilitate travelers when traveling. And also travel motivation has a significant relationship with tour preferences. The number of class divisions of the tour preferences in the 
travel agents is due to the differentiation between the motivations of the travelers who want to travel so that traveling motivation is a very close variable and cannot be separated from tour preferences. Different lifestyles of each group in society make many diverse habits, so it does not rule out when someone who has an independent lifestyle often travels alone, so his lifestyle can affect a person's intention to travel so that he can find something or someone he wants, however, travel motivation is still very influential on a person's intention to travel because when he already knows what motivation he has, it will be easy for him to decide to travel for himself, and clear tour preferences will make it easier for travelers to decide on to do traveling because they already know what they will get from the type or model of travel they are going to do. So the result from this research is all the variables have a significant relationship with each other, it can be concluded that all hypotheses also are accepted.From Table 3, all the respondents have high intention to do traveling. They conclude that Jakarta and Bandung have become the most popular destinations that respondents want to visit as well (Table 4). Furthermore, the data interpretation in this study included the outer model, inner model, mediating effect, and t-statistics test result. The outer model in PLS specified the degree of validity and reliability of the relationships between latent variables and indicators. Firstly, convergent validity occurred when the construct measurements were correlated with one another. As a general rule of thumb, outer loadings should obtain the value of 0.70 or higher, but still can be tolerated to 0.50 . If it is below the value of 0.50 , then it can be dropped from the analysis; while the 0.5 AVE score was considered satisfactory (Heffner, 2016). Items with outer loadings of 0.6 might be considered acceptable, while items with outer loadings less than 0.5 should be eliminated from analysis (Hair and Celsi, 2011). The results of the validity test are presented in Table 5, including outer loadings and AVE score.

Table 5. Convergent validity test (Source: author's calculating)

\begin{tabular}{|l|c|c|c|}
\hline Construct & Measurement item & Loading & AVE \\
\hline Lifestyle & LS1 & 0.799 & \multirow{4}{*}{0.628} \\
\cline { 2 - 3 } & LS2 & 0.802 & \\
\cline { 2 - 3 } & LS3 & 0.777 & \\
\hline \multirow{3}{*}{$\begin{array}{l}\text { Travel } \\
\text { motivation }\end{array}$} & TM1 & 0.784 & \\
\cline { 2 - 3 } & TM2 & 0.829 & \multirow{4}{*}{0.581} \\
\cline { 2 - 3 } & TM3 & 0.801 & \\
\cline { 2 - 3 } & TM4 & 0.616 & \\
\hline \multirow{2}{*}{$\begin{array}{l}\text { Tour } \\
\text { preferences }\end{array}$} & TP1 & 0.652 & \\
\cline { 2 - 3 } & TP2 & 0.894 & 0.688 \\
\cline { 2 - 3 } & TP3 & 0.887 & \\
\cline { 2 - 3 } & TP4 & 0.861 & \\
\hline \multirow{3}{*}{$\begin{array}{l}\text { Consumer } \\
\text { intention to } \\
\text { traveling }\end{array}$} & CIT1 & 0.849 & \multirow{3}{*}{0.676} \\
\cline { 2 - 3 } & CIT2 & 0.870 \\
\cline { 2 - 3 } & CIT3 & 0.742 & \\
\hline
\end{tabular}

Table 6. Discriminant validity test (Source: author's calculating)

\begin{tabular}{|c|c|c|c|c|}
\hline$(1)$ & $(2)$ & $(3)$ & $(4)$ & $(5)$ \\
\hline LS1 & 0.799 & 0.489 & 0.370 & 0.492 \\
\hline LS2 & 0.802 & 0.568 & 0.481 & 0.531 \\
\hline LS3 & 0.777 & 0.427 & 0.503 & 0.606 \\
\hline TM1 & 0.523 & 0.784 & 0.344 & 0.315 \\
\hline TM2 & 0.550 & 0.829 & 0.414 & 0.409 \\
\hline TM3 & 0.470 & 0.801 & 0.459 & 0.389 \\
\hline TM4 & 0.308 & 0.616 & 0.192 & 0.182 \\
\hline TP1 & 0.423 & 0.535 & 0.652 & 0.607 \\
\hline TP2 & 0.480 & 0.350 & 0.894 & 0.870 \\
\hline TP3 & 0.512 & 0.397 & 0.861 & 0.660 \\
\hline TP4 & 0.496 & 0.397 & 0.861 & 0.660 \\
\hline CIT1 & 0.558 & 0.372 & 0.730 & 0.849 \\
\hline CIT2 & 0.480 & 0.350 & 0.894 & 0.870 \\
\hline CIT3 & 0.722 & 0.396 & 0.480 & 0.742 \\
\hline
\end{tabular}

Invalid measurement could mystify the research objectives and data interpretations; hence, it should be removed to clearly investigate the correct measurement items and obtain desired results. Moreover, discriminant validity was an assessment to ensure that a reflective construct has the strongest relationship with its own indicators in the PLS path model (Sarstedt et al., 2017). The outer loadings and constructs were adequate yet valid, as illustrated in Table 6 .

Notes in Table 6: (1) Item, (2) Lifestyle, (3) Travel motivation, (4) Tour preferences, (5) Consumer intention to traveling.

Finally, the reliability test is vitally important for both data stability and consistency. The measurement model with composite reliability above the threshold value of 0.70 for each construct was considered satisfactory. The reliable statement item also required a Cronbach Alpha value higher than 0.60 for all constructs (Cohen and Aiken, 2003).

Table 7. Reliability test (Source: author's calculating)

\begin{tabular}{|c|c|c|c|c|}
\hline Variable & $(1)$ & $(2)$ & $(3)$ & $(4)$ \\
\hline $\begin{array}{c}\text { Lifestyle } \\
(\mathrm{X} 1)\end{array}$ & 0.706 & 0.835 & $>0.70$ & Reliable \\
\hline $\begin{array}{c}\text { Travel } \\
\text { motivation } \\
(\mathrm{X} 2)\end{array}$ & 0.765 & 0.846 & $>0.70$ & Reliable \\
\hline $\begin{array}{c}\text { Tour } \\
\text { preferences } \\
(Y 1)\end{array}$ & 0.843 & 0.897 & $>0.70$ & Reliable \\
\hline $\begin{array}{c}\text { Consumer } \\
\text { intention to } \\
\text { traveling } \\
(Y 2)\end{array}$ & 0.761 & 0.862 & $>0.70$ & Reliable \\
\hline
\end{tabular}

Notes in Table 7: (1) Cronbach alpha, (2) Composite reliability, (3) Scale, and (4) Description

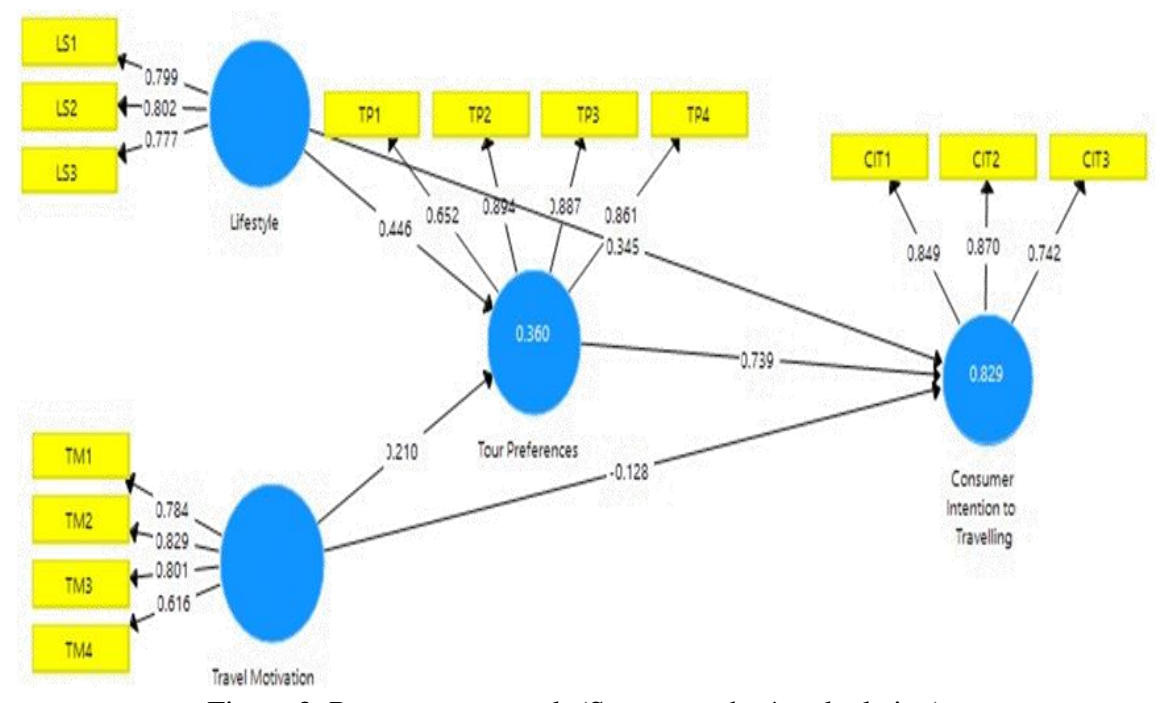

Figure 2. R-square test result (Source: author's calculating) 
Composite reliability values for all constructs fulfilled the requirement of 0.70 . The results displayed that lifestyle obtained 0.835 , travel motivation was 0.846 , tour preferences recorded 0.897 , and consumer intention to traveling was 0.862. Thereby, high composite reliability values led to the consistency of Cronbach alpha scores for all constructs. Thus, it confirmed the reliability of measurement items. Meanwhile, the structural model was also acknowledged as an inner model. It emphasized the relationships between independent and dependent latent variables. The inner model evaluation consisted of R-square measurement and path coefficient results. The coefficient of determination $\left(\mathrm{R}^{2}\right)$ indicated the differing variance in endogenous latent variables from its independent latent variables (Table 7). Conversely, if the results of $\mathrm{R}^{2}$ was 0.67 , 0.33, and 0.19, it proved that the models were subsequently 'good,' 'moderate,' and 'weak' (Hair and Celsi, 2011). Figure 2 contains the illustration of $\mathrm{R}^{2}$ test results based on SmartPLS 3.2.7 calculations.

A total of $36 \%$ specified the proportion of variance in tour preferences which was explained by lifestyle and travel motivation. $\mathrm{R}^{2}$ of $82.9 \%$ measured the ability of dependent latent variables (i.e. consumer intention to traveling) to explain the variances of independent latent variables. It was also proved that $\mathrm{R}^{2}$ was statistically significant. After assessing the quality of an outer model, it started from an evaluation of structural results by measuring path coefficient (Sanchez, 2013). Path coefficient test results offered theoretical measures of the relationship between constructs and indicators in the structural model. The numbers on the arrows in bootstrapping output were called path coefficients. The weight of different path coefficients represented the rank of each variable's relative statistical importance (Hair and Celsi, 2011). All path coefficients for each construct were positive, as illustrated in Figure 3.

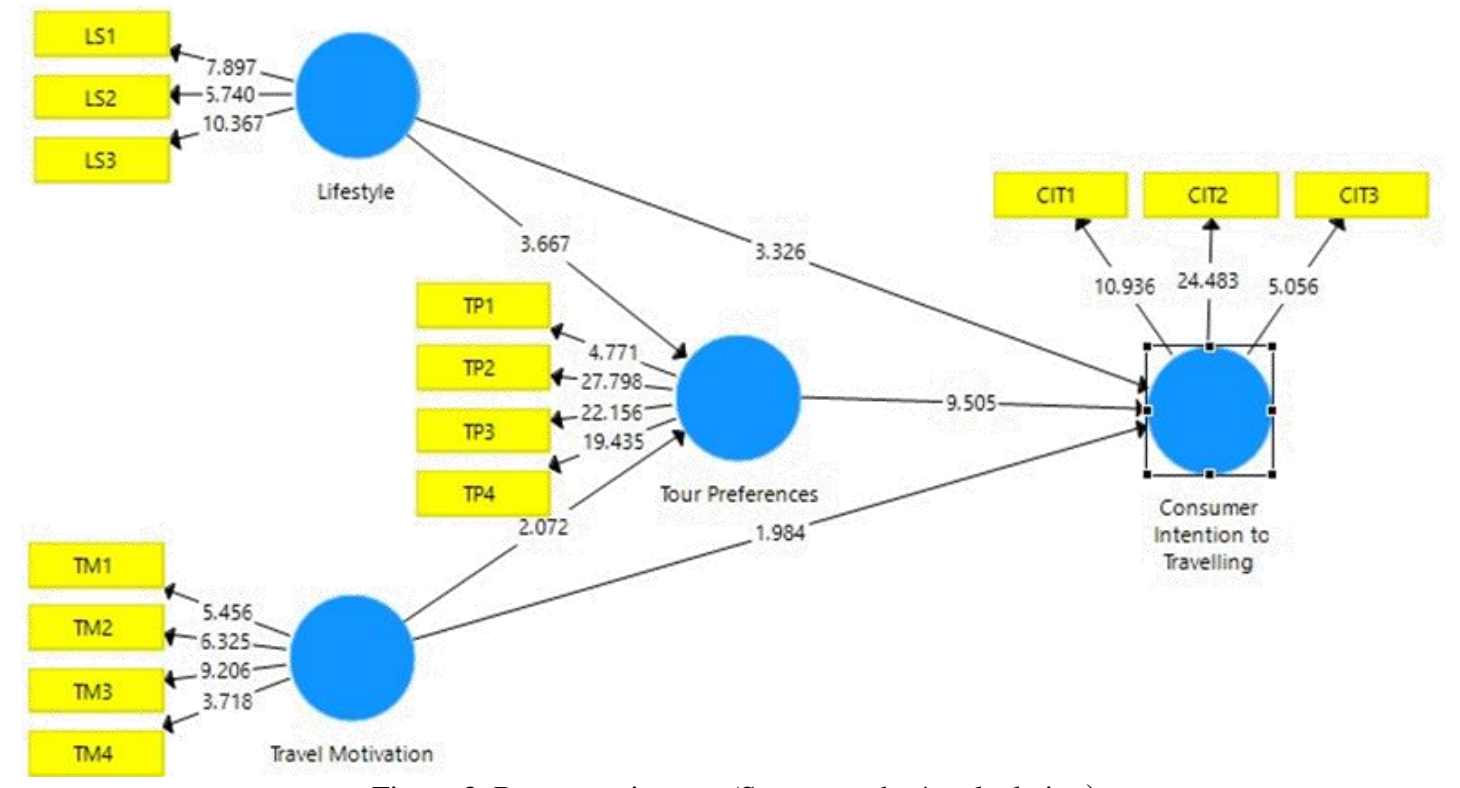

Figure 3. Bootstrapping test (Source: author's calculating)

A mediation could only occur when there was a causal effect between independent and dependent variables which is caused by an intervention or a mediating effect. In this study, the total indirect effects are shown in Table 8.

Table 8. Mediating effect (Source: author's calculating)

\begin{tabular}{|l|c|c|c|c|}
\hline \multicolumn{1}{|c|}{ Item } & $\begin{array}{c}\text { Direct } \\
\text { Effect }\end{array}$ & $\begin{array}{c}\text { Indirect } \\
\text { Effect }\end{array}$ & $\begin{array}{c}\text { Total } \\
\text { Effect }\end{array}$ & VAF \\
\hline $\begin{array}{l}\text { Lifestyle > Consumer } \\
\text { intention to traveling }\end{array}$ & 0.345 & & & \\
\hline $\begin{array}{l}\text { Lifestyle > Tour } \\
\text { preferences }> \\
\text { consumer intention } \\
\text { to traveling }\end{array}$ & 0.330 & 0.675 & $\begin{array}{c}48.89 \% \\
\text { (Partial } \\
\text { mediation) }\end{array}$ \\
\hline $\begin{array}{l}\text { Travel motivation > } \\
\text { Consumer intention } \\
\text { to traveling }\end{array}$ & 0.128 & & & \\
\hline $\begin{array}{l}\text { Travel motivation > } \\
\text { Tour preferences > } \\
\text { Consumer intention } \\
\text { to traveling }\end{array}$ & 0.155 & 0.027 & $\begin{array}{c}574 \% \\
\text { (Full } \\
\text { mediation) }\end{array}$ \\
\hline
\end{tabular}

Table 9. Hypothesis testing (Source: author's calculating)

\begin{tabular}{|l|c|c|c|c|c|c|}
\hline \multicolumn{1}{|c|}{ Item } & $(1)$ & $(2)$ & $(3)$ & $(4)$ & $(5)$ & $(6)$ \\
\hline $\begin{array}{l}\text { Lifestyle (X1) > Tour } \\
\text { preferences (Y2) }\end{array}$ & 0.446 & 0.430 & 0.125 & 3.576 & 0.000 & $\mathrm{H} 1^{*}$ \\
\hline $\begin{array}{l}\text { Travel motivation (X2) > } \\
\text { Tour preferences (Y1) }\end{array}$ & 0.210 & 0.225 & 0.098 & 2.151 & 0.032 & $\mathrm{H} 2^{*}$ \\
\hline $\begin{array}{l}\text { Lifestyle (X1) > Consumer } \\
\text { intention to traveling (Y2) }\end{array}$ & 0.345 & 0.330 & 0.099 & 3.479 & 0.001 & $\mathrm{H} 3^{*}$ \\
\hline $\begin{array}{l}\text { Travel motivation (X2) } \\
\text { Consumer intention to } \\
\text { traveling (Y2) }\end{array}$ & -0.128 & -0.120 & 0.063 & 2.038 & 0.042 & $\mathrm{H} 4 *$ \\
\hline $\begin{array}{l}\text { Tour preferences (Y1) > } \\
\text { Consumer intention to } \\
\text { traveling (Y2) }\end{array}$ & 0.739 & 0.746 & 0.078 & 9.495 & 0.000 & $\mathrm{H} 5^{*}$ \\
\hline
\end{tabular}

Notes in Table 9: (1) Original sample, (2) Sample mean, (3) Standard deviation, (4) T-statistics, (5) P-values, (6) Description, and *accepted

The mediation test was to discover if a mediating construct can significantly carry the ability of an independent variable to a dependent variable (Cohen and Aiken, 2003). Generally, a mediator was a proportion of total direct effects of exposure on the causal relationship, which was interpreted by an indirect effect. However, the total indirect effect and direct effect were both significant. If the direct path was significant, it implied that there was a mediating variable; hence, the 
bootstrapping procedure shall be redone. If the indirect path was not significant after bootstrapping, there was no mediation. If it is significant, in order to examine the strength of the mediating effect, it was recommended to calculate Variance Accounted For (VAF). There are 3 types of VAF, first if a value greater than $80 \%$ represented a full mediation, second if a value between $20 \%$ and $80 \%$ indicated a partial mediation, and last if a value less than $20 \%$ meant no mediation (Hair et al., 2014). VAF was computed by dividing total indirect effect and total effect, then multiplied by 100. Meanwhile, the total effect itself was based on the sum of direct effect and indirect effect.

As illustrated above, Table 8 implied that the lifestyle variable has $48.89 \%$ it means the relationships were classified as partial mediation, and travel motivation has $574 \%$ it means the relationships were classified as full mediation. Mediating effect's results presented in table 8 explained that all variables had mediating effects on their relationships with dependent variables. It is important to recognize that hypothesis testing aimed to test some theoretical propositions. Hypothesis testing was frequently conducted through the calculation of t-statistics or p-values for each hypothesis. The significance threshold for t-values was 1.96 for a $95 \%$ confidence level (Hair et al., 2014). Hence, if the result of a p-value is less than 0.05 or tstatistics is more than 1.96 (with $\alpha=0.05$ or $5 \%$ ), then it is assumed that an alternative hypothesis was accepted.

Table 9 presents the outputs of the standardized path coefficient related to all variables. The hypotheses were accepted and had positive direct effects on related variables. This is supported by previous research where Chen et al. (2009) explain that lifestyle attribute is a very useful assessment of tourist psychology for market segmentation research and could render practical information of tourist behaviors in developing marketing strategies and tourism preferences. The overall relationship between lifestyle and tour preferences was supported $(\beta=0.446$, $\mathrm{t}$-statistic $=3.576$, and $\mathrm{p}=0.000)$, thus, H1 is accepted. The number of class divisions of the tour preferences in the travel activities is due to the differentiation between the motivations of the travelers who want to travel so that traveling motivation is a very close variable and cannot be separated from tour preferences. This is supported by previous research where Prebensen (2016) inform that motivations are the most influencing factor and improvement in the service attributes of the journey or tourist preferences, it would contribute to increased overall satisfaction with the journey. It was concluded that there was a significant relationship between travel motivation and tour preferences $(\beta=0.210$, t-statistic $=2.151$, and $\mathrm{p}=0.032)$, thus, $\mathrm{H} 2$ is accepted.

Different lifestyles of each group in society make many diverse habits, so it does not rule out when someone who has an independent lifestyle often travels alone, so his lifestyle can affect a person's intention to travel so that he can find something or someone he wants. This is supported by previous research Bandara et al. (2016) they stated that lifestyles are the genesis for many vacation behaviors and additionally pointed out that lifestyle differences are more influential in determining vacation behaviors. The result indicated that lifestyle had a significant, positive relationship with consumer intention to traveling $(\beta=0.345$, t-statistic $=3.479$, and $\mathrm{p}=0.001)$, thus $\mathrm{H} 3$ is accepted. Travel motivation is very influential on a person's intention to travel because when he already knows what motivation he has, it will be easy for him to decide to travel for himself. Based on the previous research by March and Woodside (2005) they stated that Travel motivation can drive people from the inside, it's a person's wants. People tend to move because of what they want, and that is how to travel motivation works, when they know what exactly they want it makes them easy to do traveling.

A significant, positive relationship between travel motivation and consumer intention to traveling was supported $(\beta=-$ 0.128 , t-statistic $=2.038$, and $\mathrm{p}=0.042$ ), thus $\mathrm{H} 4$ is accepted. A significant, positive relationship between tour preferences and consumer intention to traveling was supported $(\beta=-0.739$, t-statistic $=9.495$, and $p=0.000)$, thus H5 is accepted. This is in line with the previous study by Ashworth and Goodall (1990) they stated travel preference is one of the options that can give an insight of the traveler to do travel with the kind of model traveling they want.

\section{CONCLUSION AND LIMITATION}

The level of respondent intention to traveling is progressively growing in recent years. As the internet offers the better speed connection it makes it easier for people around the world to share their life activities in social media, and they can manage to enhance their popularity among other with showing their picture especially traveling activities. Travel motivation adds more customer value to choose the traveling model they want, and it will make them easy to understand what they are searching for from these activities. Since tour preferences have the highest significant relationship towards consumer intention to traveling, the tourism businesses need to focus on efforts to generate consumers' memory about travel type specifications. Promotion efforts through advertising and public relation are recommended because there are still few advertisements related to tourist sites and especially for domestic destinations which enhance the tourism business sector in Indonesia.

This research also has some limitations. Firstly, it has geographical limitations. Secondly, it only has a small number of samples. Thirdly, few theoretical supports provide some limited space to explore this topic. More than that this research has lacks resources and we hope for future studies can add more variables and implement this topic for different places. A comparison between two or more different destinations is strongly recommended. Lifestyle is one of the most significant variables in this research. Hence, future studies can compare different types of lifestyles in each generation. Further study can add more variables to determine a causal relationship between tour preferences and consumer intention to travel.

\section{REFERENCES}

Abbey, J. (2004). Hospitality sales and marketing. El-Ahla, New York.

Ajzen, I. (2020). The theory of planned behavior: Frequently asked questions. Human Behavior and Emerging Technologies, 2(4), $314-324$. https://doi.org/10.1002/hbe2.195

Ashworth, G., \& Goodall, B. (1990). Marketing tourism places. Routledge, London.

Backman, K.F., Backman, S.J., \& Silverberg, K.E. (1999). An investigation into the psychographics of senior nature-based travellers. Tourism Recreation Research, 24(1), 13-22. https://doi.org/10.1080/02508281.1999.11014853 
Bandara, B.E., De Silva, D.A., Maduwanthi, B.C., \& Warunasinghe, W.A. (2016). Impact of food labeling information on consumer purchasing decision: With special reference to faculty of agricultural sciences. Procedia Food Science, 6, 309-313. https://doi.org/10.1016/j.profoo.2016.02.06

Calantone, R.J., \& Johar, J.S. (1984). Seasonal segmentation of the tourism market using a benefit segmentation framework. Journal of Travel Research, 23(2), 14-24. https://doi.org/10.1177/004728758402300203

Chen, J.S., Huang, Y.C., \& Cheng, J.S. (2009). Vacation lifestyle and travel behaviors. Journal of Travel \& Tourism Marketing, 26(5-6), 494-506. https://doi.org/10.1080/10548400903163038

Chivandi, A., Samuel, O., \& Muchie, M. (2020). The effect of online travel agencies (OTA) on brand relationships in low and high-end hotels in South Africa. GeoJournal of Tourism and Geosites, 31(3), 951-957. https://doi.org/10.30892/gtg.31303-526

Cizmar, S., \& Weber, S. (2000). Marketing effectiveness of the hotel industry in Croatia. International Journal of Hospitality Management, 19(3), 227-240. https://doi.org/10.1016/S0278-4319(00)00020-7

Cohen, J., Cohen, P., West, S.G., \& Aiken, L.S. (2003). Applied multiple regression/correlation analysis for the behavioral sciences (3rd ed.). Lawrence Erlbaum Associates Publishers, New Jersey.

Darma, D.C, Maria, S., Kasuma, J., \& Lestari, D. (2020). Factors involved in the number of tourist visits in the Muara Badak, Indonesia. Religación. Revista De Ciencias Sociales Y Humanidades, 5(24), 142-151. https://doi.org/10.46652/rgn.v5i24.623

Decrop, A. (2006). Vacation decision-making. CABI-Publishing, Wallingford.

Dimock, M. (2015). Defining generations: Where millennials end and generation $Z$ begins. https://www.pewresearch.org/facttank/2019/01/17/where-millennials-end-and-generation-z-begins/

Fishbein, M., \& Ajzen, I. (1975). Belief, attitude, intention, and behavior: An introduction to theory and research. Addison-Wesley, Reading, MA.

Gerrig, J.R., \& Zimbardo, G.P. (2002). Psychology and life, 16th ed. Allyn and Bacon, Boston.

González, A.M., \& Bello, L. (2002). The construct "lifestyle" in market segmentation: The behaviour of tourist consumers. European Journal of Marketing, 36(1/2), 51-85. https://doi.org/10.1108/03090560210412700

Hair, J.F, \& Celsi, M. (2011). Essentials of business research methods. M.E Sharpe, New York.

Hair, J.F., Sarstedt, M., Hopkins, L., \& Kuppelwieser, G.V. (2014). Partial least squares structural equation modeling (PLS-SEM). European Business Review, 26(2), 106-121. https://doi.org/10.1108/ebr-10-2013-0128

Hair, J.F., Howard, M.C., \& Nitzl, C. (2020). Assessing measurement model quality in PLS-SEM using confirmatory composite analysis. Journal of Business Research, 109, 101-110. https://doi.org/10.1016/j.jbusres.2019.11.069

Heffner, C.L. (2016). Test validity and reliability. AllPsych. http://allpsych.com/researchmethods/validityreliability/

Hsu, J.L., \& Chang, K.M. (2008). Purchase of clothing and its linkage to family communication and lifestyles among young adults. Journal of Fashion Marketing and Management, 12(2), 147-163. https://doi.org/10.1108/13612020810874854

Jannah, N., Antara, M., \& Effendy, E. (2018). Faktor-faktor yang mempengaruhi perilaku konsumen dalam mengkonsumsi buah jeruk impor di Kota Palu [Factors that influence consumer behavior in consuming imported citrus fruits in Palu City]. Jurnal Agroland, 25(2), 121-129.

Kala, N., Abaydeldinov, Y., Furman, T., \& Ponomarev, A. (2017). The world tourism organization for countering terrorist threats. Journal of East Asia and International Law, 10(2), 549-550. https://doi.org/10.14330/jeail.2017.10.2.11

Kamri, T., Kasuma, J., Kutok, J., \& Darma, D.C. (2020). Do tourists willing to pay for the value of environmental conservation? A case of Annah Rais Longhouse and Hot Springs. Journal of Tourism Management Research, 7(2), 218-228. https://doi.org/10.18488/journal.31.2020.72.218.228

Kozak, M. (2002). Comparative analysis of tourist motivations by nationality and destinations. Tourism Management, $23(3), 221-232$. https://doi.org/10.1016/S0261-5177(01)00090-5

March, R., \& Woodside, A.G. (2005). Tourism behavior: Travelers' decisions and actions. CABI Publishing, Cambridge.

Mill, R.C., \& Morrison, A. (1985). The tourism system: An introductory text. Prentice Hall, Engllewood Cliffs, NJ.

Mohamad, D., \& Jamil, R.M. (2012). A preference analysis model for selecting tourist destinations based on motivational factors: A case study in Kedah, Malaysia. Procedia - Social and Behavioral Sciences, 65, 20-25. https://doi.org/10.1016/j.sbspro.2012.11.085

Oppermann, M. (1999). Where psychology and geography interface in tourism research. Consumer psychology of tourism, hospitality and leisure, pp. 19-38. https://www.cabdirect.org/cabdirect/abstract/19991811755

Parubak, B. (2010). Faktor-faktor yang dipertimbangkan konsumen dalam pembelian kain Donggala di Kotamadya Palu [Factors that consumers consider in purchasing Donggala fabrics in the Municipality of Palu]. Jurnal Wacana, 13(4), 592-605.

Plummer, D.T. (1979). An introduction to practical biochemistry, second edition. Tata McGaraw-Hill Publishing Company, New Delhi.

Prasetijo, R., \& Ihalauw, J. (2005). Perilaku konsumen [Consumer behavior]. Andi Offset, Yogyakarta.

Prebensen, N.K. (2016). Tourist satisfaction with a destination. Finnmark College, Norway.

Ratnasari, S., Susanti, E., Ismanto, W., Tanjung, R., Darma, D.C, \& Sutjahjo, G. (2020). An experience of tourism de velopment: How is the strategy?. Journal of Environmental Management and Tourism, 11(7), 1877-1886. https://doi.org/10.14505//jemt.v11.7(47).26

Ritchie, J.R., \& Crouch, G. (2000). The competitive destination: A sustainability perspective. Tourism Management, 21(1), 1-7. https://doi.org/10.1079/9780851996646.0000

Sanchez, G. (2013). PLS path modeling with R, Trowchez editions. Berkeley, New York.

Sarstedt, M., Ringle, C.M., \& Hair, J.F. (2017). Partial least squares structural equation modeling. In: Homburg C., Klarmann M., Vomberg A., Handbook of Market Research, Springer, Cham. https://doi.org/10.1007/978-3-319-05542-8_15-1

Suharto, R.B., Roy, J., \& Darma, D.C. (2019). Degree of potential and development strategy of tourism objects. International Journal of Scientific and Technology Research, 8(9), 2343-2347.

Tran, X., Nguyen, B.L., \& Nguyen, M.C. (2015). Effects of the big five personality traits on recreation types - the case of Vietnam tourism. Travel and Tourism Research Association: Advancing Tourism Research Globally, 14. https://scholarworks.umass.edu/ttra/ttra2015/Academic_Papers_Oral/14

Ushakov, D.S., Samonova, T.B., Haiovyi, I.I., Minich, I.M., \& Didenko, K.D. (2020). Transnational players in tourism: Regional features of functioning. GeoJournal of Tourism and Geosites, 32(4), 1425-1432. https://doi.org/10.30892/gtg.32434-590

Vuuren, C.V., \& Slabbert, E. (2012). Travel motivations and behavior of tourist to a South African resort. International Conference on Tourism \& Management Studies, Book of Proceedings, 1, 295-304.

Zins, A.H. (1998). Leisure traveler choice models of theme hotels using psychographics. Journal of Travel Research, 36(4), 3-15. https://doi.org/10.1177/004728759803600401 